\title{
Determinants of entrepreneurial intentions: the case of Southern Romania
}

\author{
Sorin-George TOMA \\ University of Bucharest, Bucharest, Romania \\ tomagsorin62@yahoo.com \\ Paul MARINESCU \\ University of Bucharest, Bucharest, Romania \\ paulmarinescu1@gmail.com \\ Ionuț CONSTANTIN \\ University of Bucharest, Bucharest, Romania \\ ionut.constantin@drept.unibuc.ro
}

\begin{abstract}
The study of entrepreneurial intentions has become a topic of interest in the last decades. As most of the decisions to launch a new firm are assumed to be planned for some time, it means that they are preceded by an intention to do so. Thus, identifying and analyzing the factors that influence the entrepreneurial intention represents a key issue in the entrepreneurship research. A review of the scientific literature shows that the determinants of entrepreneurial intentions are to be found in both the psychological approach and the behavioral approach. The psychological approach stresses the importance of various factors such as the locus of control, the propensity to take risk, the self-confidence, the need for achievement, or the innovativeness. On its turn, the behavioral approach puts accent on other elements such as the subjective norms or the personal attitude. The purpose of the paper is to identify and analyze the determinants of entrepreneurial intentions in the case of the Romanian entrepreneurs located in the Southern part of the country. In this respect, it takes into account several factors such as gender, experience or propensity towards risk. The methodological approach was based on a quantitative research method. The method of data collection was a survey by self-administered questionnaire. The paper illustrates the existence of various correlations between the above factors and the entrepreneurial intentions. It contributes to the enrichment of the scientific literature by emphasizing the role played by some of the main determinants of entrepreneurial intentions in the developing of entrepreneurship in Southern Romania.
\end{abstract}

Keywords: entrepreneurial intentions, entrepreneurs, entrepreneurship, gender, business, Romania.

\section{Introduction}

In the last decades entrepreneurship has gained increased recognition as one of the main growth engines of the world economy. In spite of the fact that the large companies are dominating the global economy as 10 percent of them are generating around 80 percent of all profits (World Bank, 2019) the appreciation for the role entrepreneurship plays in society is expanding (Bosma \& Kelley, 2018). The entrepreneurial firms, such as small and medium-sized enterprises (SMEs), account for the vast majority of businesses, contribute to sustainable development, create new jobs, enhance economic resilience and improve social cohesion (Moreira et al., 2018; Organization for Economic Co-operation and Development, 2019). For example, there were more than 25 million SMEs in the European Union (99.8\% of all enterprises) in 2018 (European Commission, 2019). As entrepreneurship represents a complex and multifaceted phenomenon (Low \& McMillian, 1988; Toma et al., 2014), the need to understand entrepreneurship has constantly grown throughout the world. 
In the beginning, researchers concentrated their attention especially on defining the entrepreneur and its behavior. The trait perspective illustrates the characteristics and dispositions of the entrepreneur (e.g., personality) whereas the behavioral approach points out the activities undertaken by him (e.g., gathering resources) in the creation of a business (Gartner, 1988). Later, the focus of entrepreneurship research expanded towards other subjects such as the environmental factors, the business opportunities, the cognitive processes, or the entrepreneurial intentions (Blanchflower \& Oswald, 1998; McKenzie et al., 2007; Walter \& Heinrichs, 2015).

The study of entrepreneurial intentions has become an important topic of interest in the past decades. As most of the decisions to launch a new firm are assumed to be planned for some time, it means that they are preceded by an intention to do so. Since the 1980 s several intention models have been designed by researchers in order to describe and explain the early entrepreneurial process and the entrepreneurial behavior such as those proposed by Shapero and Sokol, or Ajzen (Rai et al., 2017). Thus, identifying and analyzing the factors that influence the entrepreneurial intention represents a key issue in the entrepreneurship research. Based on these issues the paper proposes to address the following research question: Which are the main determinants of entrepreneurial intentions in the case of the Romanian entrepreneurs located in Southern Romania?

The purpose of the paper is to identify and analyze the determinants of entrepreneurial intentions in the case of the Romanian entrepreneurs located in the Southern part of the country. In this respect, it takes into account several factors such as gender, experience or propensity towards risk.

The paper is organized as follows. The next section presents the literature review. The third part describes the research methodology. The results and discussions are exposed in the fourth section. The paper ends with conclusion.

\section{Literature review}

This section furnishes an overview of the principal notions of the paper by taking into account the studies published in the scientific literature. There are numerous definitions of the term of entrepreneurship because it has been studied by scholars belonging to different domains (e.g., psychology, sociology, business administration). As a process of organization creation (Gartner et al., 1992), entrepreneurship is "the set of behaviors that initiates and manages the reallocation of economic resources and whose purpose is value creation through those means" (Herron \& Robinson Jr., 1993, p. 283). As a mindset, entrepreneurship "covers an individual's motivation and capacity, independently or within an organization, to identify an opportunity and to pursue it in order to produce new value or economic success" (European Commission, 2003, p. 5). Also, it is seen as "an attitude that reflects an individual's motivation and capacity to identify an opportunity and to pursue it" (Yildirim et al., 2016, p. 278). The above definitions emphasize the need of a multidimensional approach of entrepreneurship and illustrate its relationship with various notions such as behavior, motivation, attitude, or mindset.

On its turn, grounded on cognitive psychology, the concept of intentionality is defined as a "state of mind directing a person's attention (and therefore experience and action) toward a specific object (goal) or a path in order to achieve something (means)" (Bird, 1988, p. 442). As a cognitive construct, intention represents a psychological "process, state, or act of conscious willing in the present to make some experience be true, realized, manifested, or created in the future" (Bird, 1983, p. 2). In the case of entrepreneurship, intention is related to attaining an entrepreneurial identity, pursuing an entrepreneurial career, or obtaining a specific outcome, and, therefore, leads to action (Bird, 2015). Thus, the entrepreneurial intention constitutes a cognitive representation of the 
actions to be carried on by an individual, either to found a new venture or to create new value within an established firm (Bird, 1988; Fini et al., 2012). During the formulation of entrepreneurial intentions, two blocks, namely the social, political and economic context (e.g., market changes) and the personal history, current personality and abilities (e.g., previous entrepreneurial experience), interact both with two types of thinking: rational, analytic, and cause-effect thinking (e.g., goal setting) and intuitive, holistic, and contextual thinking (e.g., feelings) (Bird, 1988).

PICBE | 113

The attempts to reveal and analyze the determinants of entrepreneurial intentions have led to the emergence of intentions-based models and theories. Shapero and Sokol's (1982) model of entrepreneurial event shows that entrepreneurial intentions emanate from three elements: perceived desirability, propensity to act, and perceived feasibility. The perceived desirability illustrates the attractiveness of launching a venture, the propensity to act represents one's disposition to take action, and the perceived feasibility indicates how capable a person feels to start a business.

Originated in the theory of reasoned action (Fishbein \& Ajzen, 1975; Ajzen \& Fishbein, 1980), the theory of planned action places at its core the individual's intention to follow a given behavior. Intention is a function of the individual attitude toward the behavior, the subjective norm, and the perceived behavior control (Figure 1). The individual attitude represents a person's complete judgement of whether following the given behavior is good/bad, the subjective norm is his/her belief that persons who are important to him/her consider that he/she should/should not follow the behavior, and the perceived behavioral control embodies his/her assessment of the probability of successfully following the intended behavior (Ajzen, 1991).

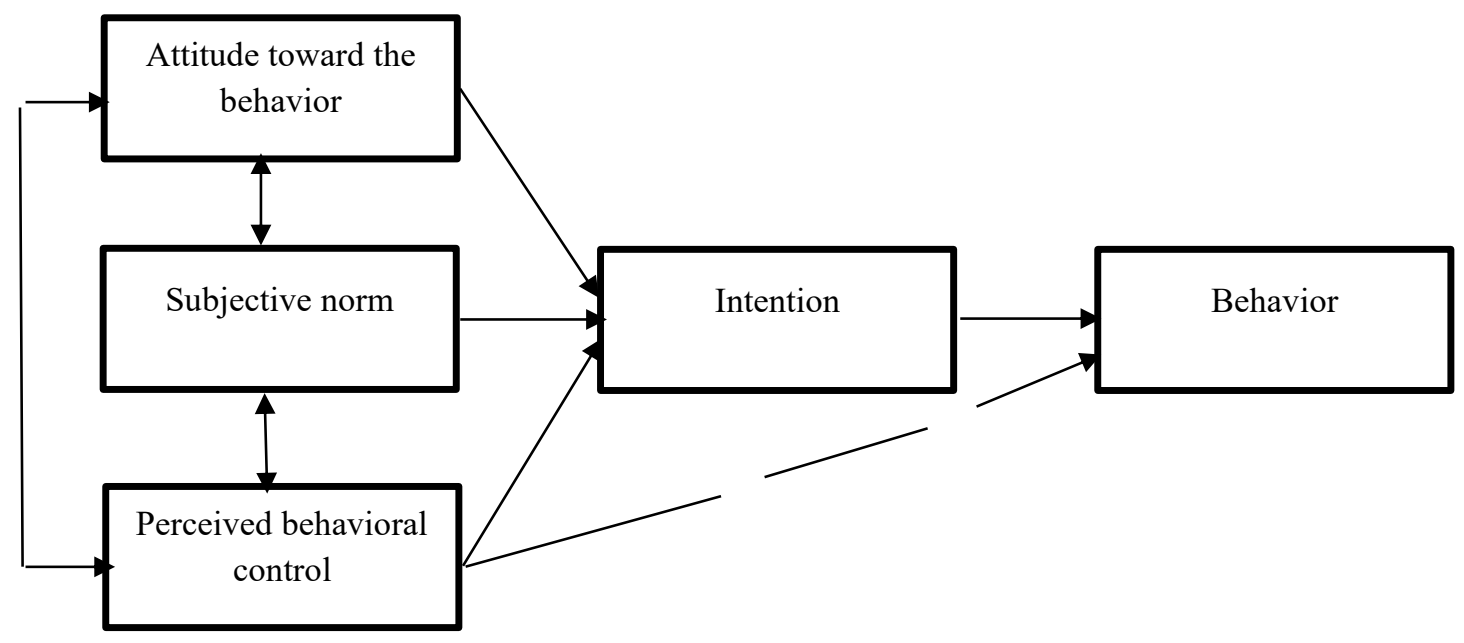

Figure 1. Ajzen's theory of planned behavior

Source: Ajzen, 1991.

An integrated model of entrepreneurial intentions is provided by Iakovleva and Kolvereid (2009). It shows that intention is a function of the couple desirability-feasibility, which in turn is a function of three elements: attitudes, subjective norms, and perceived behavioral control.

In sum, the determinants of entrepreneurial intentions are to be found in both the psychological approach and the behavioral approach (Ferreira et al., 2012). The psychological approach stresses the importance of various factors such as the locus of control, the propensity to take risk, the self-confidence, the need for achievement, or the innovativeness. On its turn, the 
behavioral approach puts accent on other elements such as the subjective norms or the personal attitude.

\section{Methodology}

The authors used a quantitative research method. The method of data collection was a survey by selfadministered questionnaire, carried on in the period 02-23.12.2019. A questionnaire was sent by the authors through Internet to a total sample of 93 respondents from 13 counties, as follows: 46 respondents from the SUCCESS project and 47 respondents from the DREAM project. The respondents are individuals who have had the opportunity to start a business through these two projects. Both projects address future entrepreneurs from Southern Romania. The respondents from the SUCCESS project are from seven Romanian counties: Arges, Calarasi, Prahova, Dambovita, Ialomita, Teleorman and Giurgiu, whereas the respondents from the DREAM project are from the following six counties: Constanta, Tulcea, Braila, Galati, Buzau and Vrancea. Therefore, our research took into consideration potential entrepreneurs from 13 counties located in Southern Romania. These projects have been co-financed by the European Social Fund through the Human Capital Operational Program (POCU) 2014-2020 "Romania Start-up Plus!" Priority Axis No. 3, Jobs for All, Operation: Increasing employment by supporting non-agricultural enterprises in the urban area. Also, the authors obtained the list of NACE codes specific to the businesses of the respondents in order to formulate proper questions.

The questionnaire encompassed 26 questions and were aimed at obtaining data on various subjects such as the existence of a business, the intention to start-up a business, the field in which the business could be opened, the business experience of the respondents, their ability to determine what types of knowledge are useful to a business, the occupational status, the existence of other concerns besides the entrepreneurial status, the field of activity in which the respondents work, the fields of graduated studies and their current income. The data were processed through the Excel software program. The main research hypothesis was the following:

H1. The determinants of entrepreneurial intentions in the case of the Romanian entrepreneurs located in Southern Romania are related to both psychological and behavioral factors.

\section{Results and discussions}

The great advantage of the research is that all respondents from both projects won the competition on financing their businesses. More than 300 Romanian competitors, who elaborated business plans, were registered at the beginning of the projects, and 93 of them received funding. Thus, the research was addressed only to those entrepreneurs who won the competition and demonstrated the viability of their business plans.

The analysis of the data has shown that there are sensitive differences between the choices that women make and the choices that men make related to their businesses. In this respect, male respondents decided to start businesses in fields such as industry, tourism, consultancy, agriculture, and trade, while female respondents in areas such as financial-banking (services), accounting, education, care and beautification and agriculture. As for female respondents, $27 \%$ of them come from rural areas, and $73 \%$ of them from urban areas. As for male respondents, $33 \%$ of them come from rural areas, and 67\% come from urban areas (Figure 2). The results indicate that there is a relative equilibrium between female and male respondents in relation to their residence.
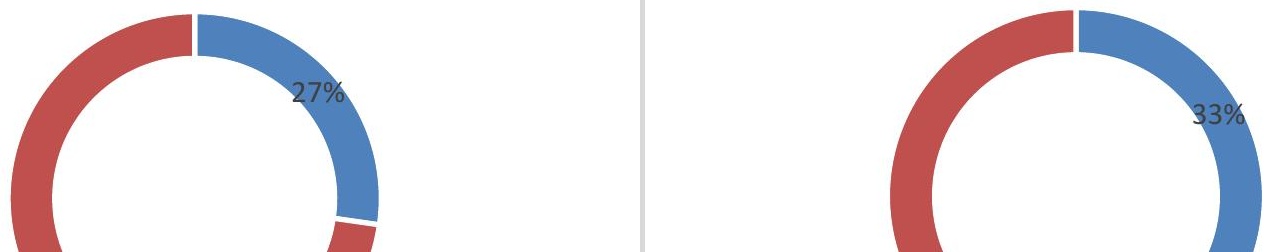
Figure 2. Respondents' residence

Source: Authors' own research.

Regarding their overall business experience, $10 \%$ of women believe that they have significant business experience, and $30 \%$ of men believe that they have great or very high business experience (Figure 3). Most of them consider that they have little or medium experience.

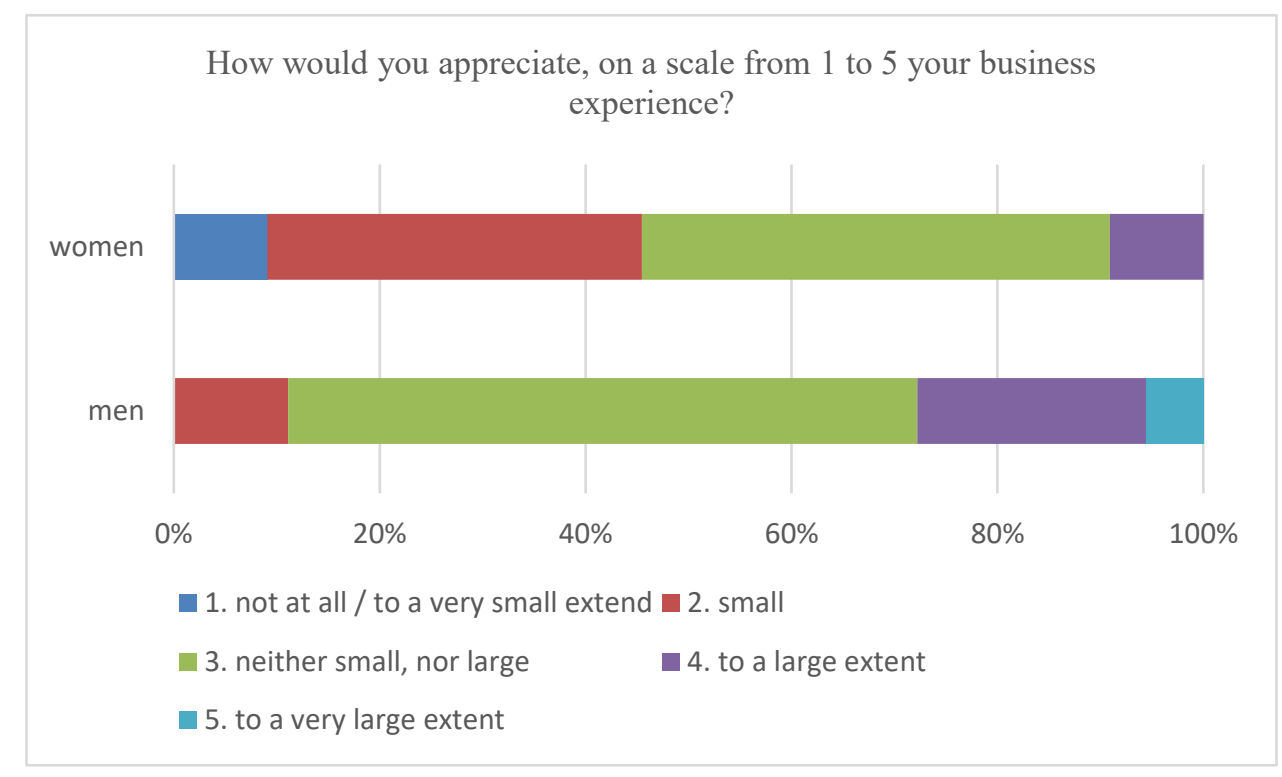

Figure 3. Respondents' business experience

Source: Authors' own research.

In relation to their previous experience in various business areas, women consider that they have experience in the following fields: services/production, marketing and accounting, while men believe that they have experience in the fields of: services/production, obtaining financing for starting of a business, supply, sales, marketing, legal aspects (registrations, contracts, etc.) and business planning (Figures 4 and 5) . 
To what extent do you have experience in the following areas of a business:

Technical aspects: Production / Services

Obtaining financing for starting of a business

Supply

Sales

Marketing

Financial Management

Accounting

Staff Management

Legal aspects (registrations, contracts)

Business planning

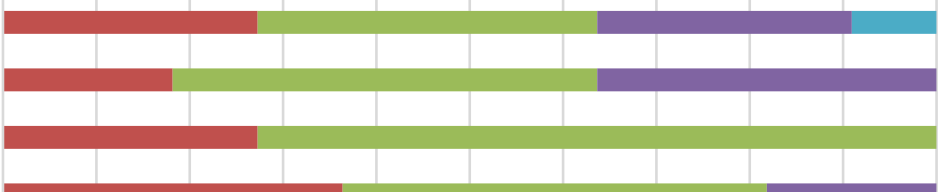

[CBE $\mid 116$

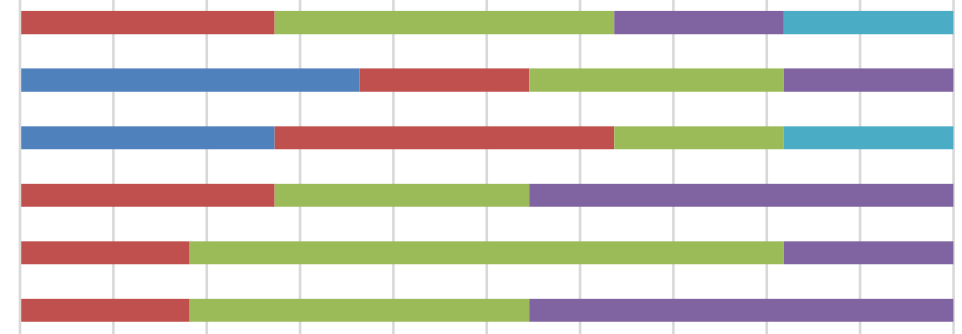

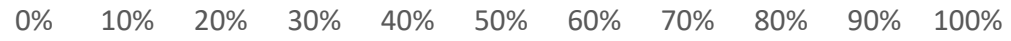

1. not at all / to a very small extend $\square 2$. small

3. neither small, nor large

4. to a large extent

5. to a very large extent

Figure 4. The experience of female respondents in specific areas of as business.

Source: Authors' own research.

The results illustrate that $33 \%$ of women consider that they have great and very high experience in the field of services in comparison with $61 \%$ of men. In connection with obtaining funding for starting a business, 33\% of women believe they have relevant experience in this field in compariosn with $45 \%$ of men. In terms of experience in the field of supply, women believe that they do not have relevant experience, and $63 \%$ of men believe that they have great and very high business experience in such field. 
To what extent do you have experience in the following areas of a business:

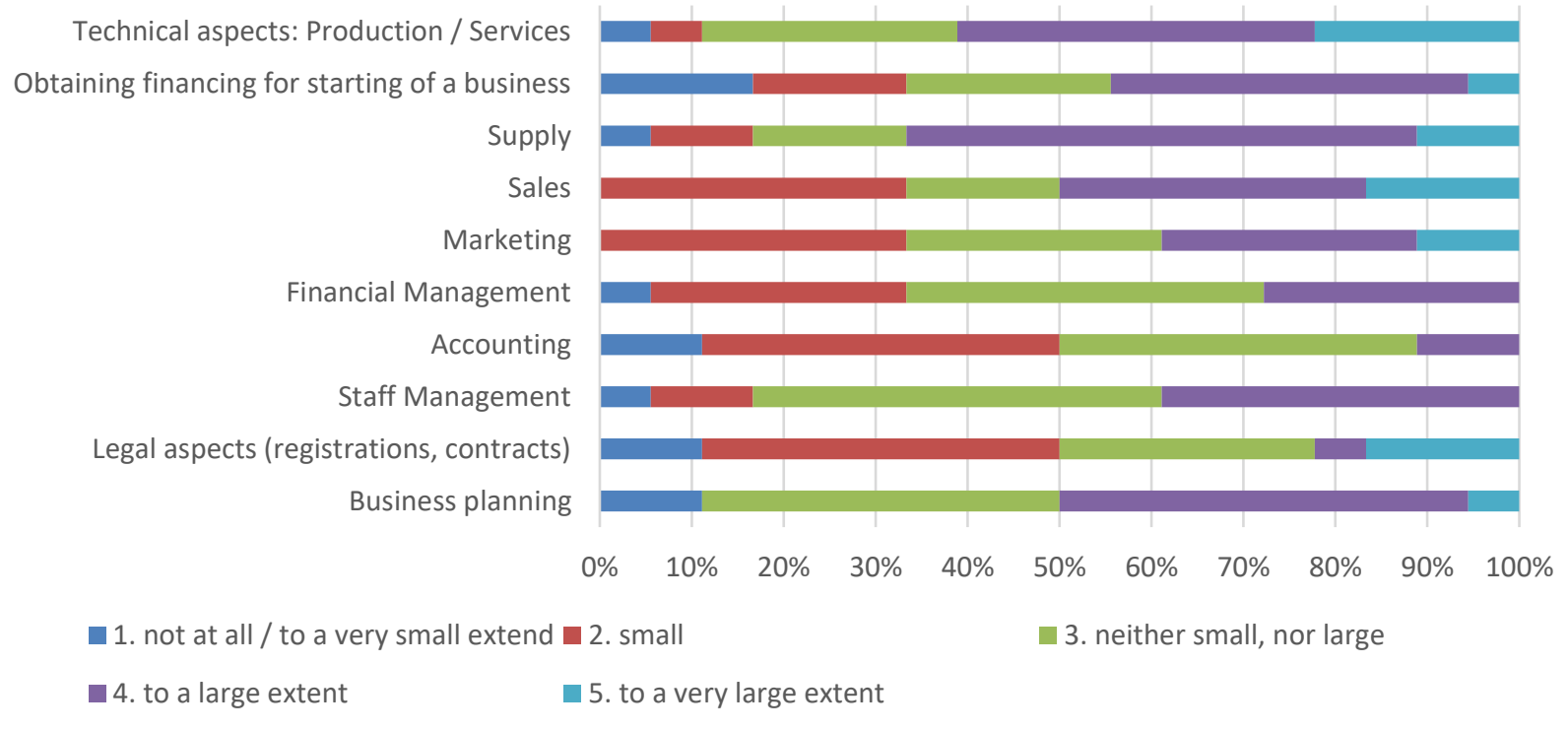

Figure 5. The experience of male respondents in specific areas of as business.

Source: Authors' own research.

In staff relations, $43 \%$ of women and $39 \%$ of men believe that they have great experience in staff management. In terms of knowledge of legal regulations, the ability to obtain legal documents related to the establishment of a company and the concluding of agreements, $18 \%$ of women believe that they have very high experience and $22 \%$ of men believe that they have great and very high experience. Business planning activities reveal that $45 \%$ of women believe they have great experience, and $50 \%$ of men think they have great and very high experience.

Also, $72 \%$ of women and $90 \%$ of men believe that entrepreneurs bring certain benefits to society (Figure 6 and 7$)$. Interesting is the fact that men are more tempted $(28 \%)$ than women (9\%) to start a business abroad. Regarding their adaptability and mobility, $18 \%$ of women believe that they are largely willing to start a business in another locality than their residence in comparison with $50 \%$ of men. 
To what extent do you agree with the following statements:

In today's Romania the entrepreneur is the person who brings benefits to the society

To have a good business I'd be willing to go to another country

To have a good business I'd be willing to go to another locality

I would prefer a small, personal or family business than a large one with many employees

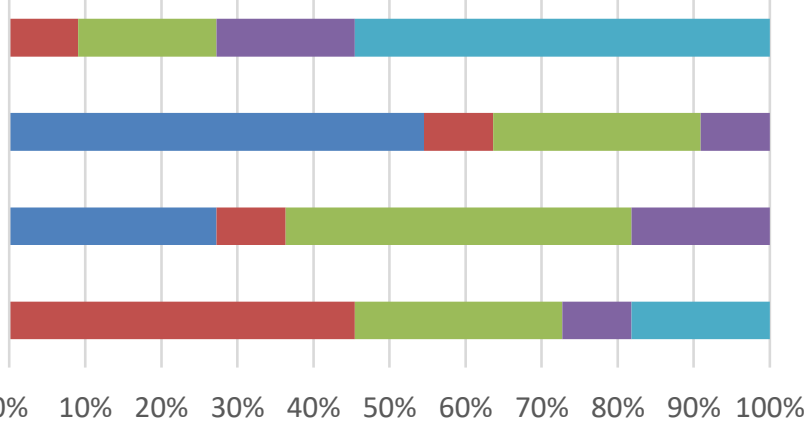

$\square$ 1. not at all / to a very small extend $\square 2$. small

3. neither small, nor large

4. to a large extent

5 . to a very large extent

Figure 6. Views on entrepreneurship - female respondents.

Source: Authors' own research.

To what extent do you agree with the following statements:

In today's Romania the entrepreneur is the person who brings benefits to the society

To have a good business I'd be willing to go to another country

To have a good business I'd be willing to go to another locality

I would prefer a small, personal or family business than a large one with many employees

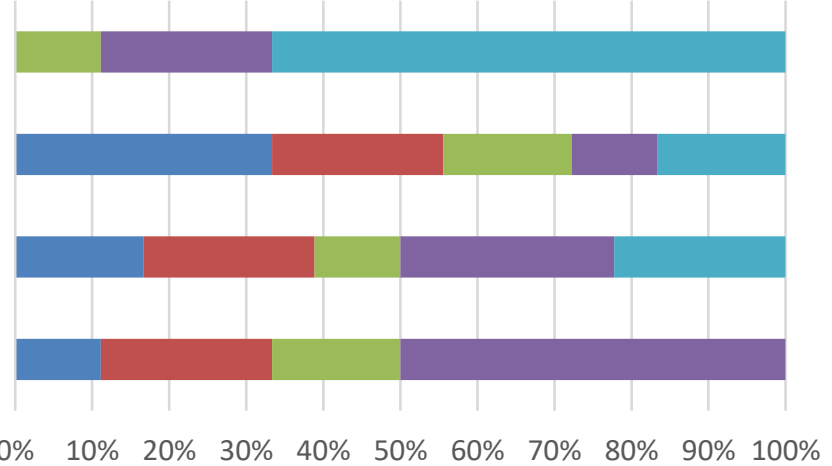

ש1. not at all / to a very small extend $\boldsymbol{\square}$ 2. small

3. neither small, nor large

4. to a large extent

5. to a very large extent

\section{Figure 7. Views on entrepreneurship - male respondents.}

Source: Authors' own research.

Regarding the individual's risk propensity, the results provide valuable information about his/her vision in terms of the risk he/she takes: $28 \%$ of women accept the idea that they are willing to open a small, personal or family business, to a large or a very large extent, in comparison with half of men. Thus, $50 \%$ of the men are willing to start a large business. 
Another question took into account the respondents' opinion on the usefulness of different courses/disciplines- the authors choose 12 relevant disciplines: sales management, labour law, strategic management, production and service management, human resources management, quality management, accounting, finance, marketing, management, business/commercial law, entrepreneurship- in order to obtain the needed skills for running business. On the one hand, the answers show the professional experience of the respondents, and, on the other hand, the needs they have in terms of business skills and knowledge. Thus, 54\% of women considered that sales management to be very useful for running a business in comparison with $32 \%$ of men (Figures 8 and 9). This result is interesting because, in general, there is a perception that men have higher availability for the sales field. Also, the data show that $33 \%$ of women and $21 \%$ of men consider that labour law is very useful, and $32 \%$ of women and $37 \%$ of men consider the same subject to be useful.

On its turn, the strategic management course has been appreciated as being very useful by $52 \%$ of women and $24 \%$ of men, and useful by $33 \%$ of women and $32 \%$ of men. In terms of production and service management, $37 \%$ of women find it very useful and $42 \%$ of men find it very useful, $42 \%$ of women and $27 \%$ of men find it useful. The analysis of the importance of the human resources management topic show that $75 \%$ of women consider it useful and very useful in comparison with $69 \%$ of men.

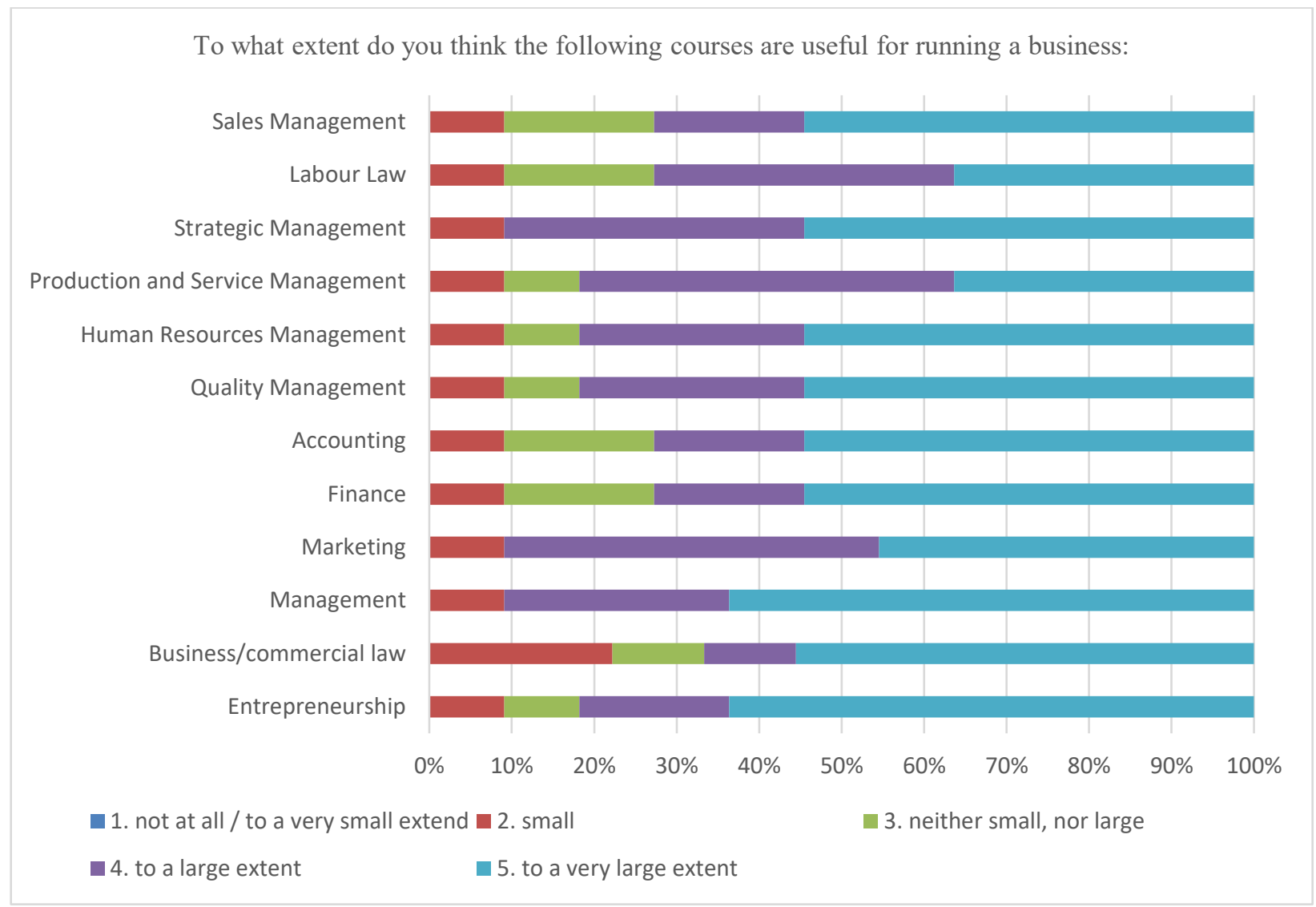

Figure 8. Useful courses/disciplines for running a business - female respondents.

Source: Authors' own research. 
To what extent do you think the following courses are useful for running a business:

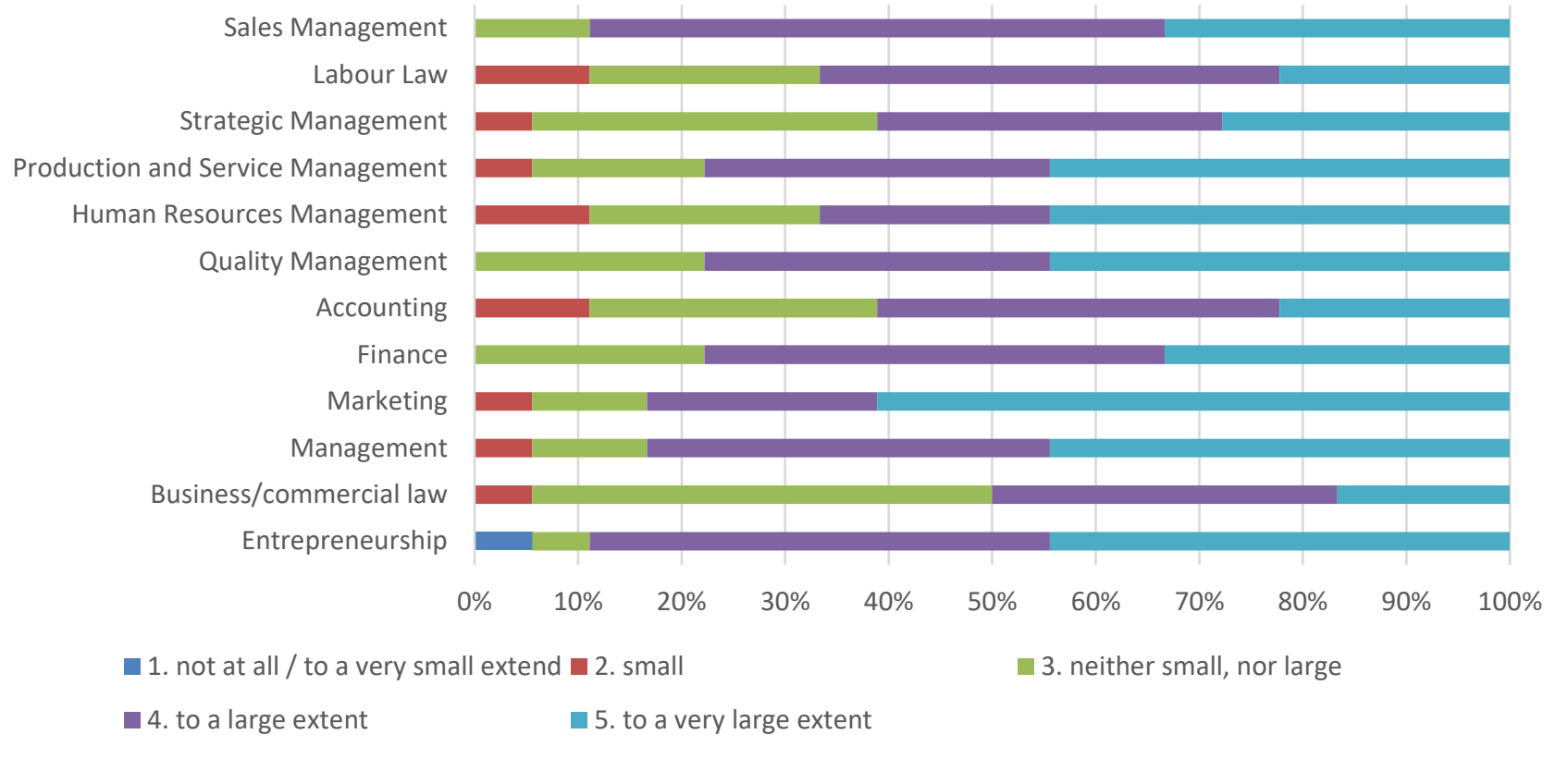

Figure 9. Useful courses/disciplines for running a business - male respondents.

Source: Authors' own research.

In relation to the quality management topic, $52 \%$ of women think it is very useful and $23 \%$ of them think it is useful, and $42 \%$ of men think it is very useful and $27 \%$ of them think it is useful. Accounting is, from the perspective of $52 \%$ of women very important, and important for $13 \%$ of them whereas for $11 \%$ of men this subject is considered very important and important for $34 \%$ of them. The importance of the finance course is as follows: for $52 \%$ of women is very useful and useful for $15 \%$ of them, and for $32 \%$ of men is very useful and useful for $36 \%$ of them. The research also took into account the relevance of the subject that defines market relations (marketing). We learn here that $42 \%$ of women find it very useful, and $43 \%$ find it useful, and $61 \%$ of men find it very useful and $22 \%$ find it useful. The subject of management provides interesting information about the perspective of women and men about its importance in the quality of carrying out a business, $62 \%$ of women consider it very important, and $28 \%$ consider it important. From the perspective of the male respondents, $42 \%$ of them consider it very important, and $38 \%$ consider it important. The role of legal regulations in the existence of a business is shown by the answers that respondents have given in terms of the relevance of business/commercial law subject matter. Thus, $52 \%$ of women consider this subject to be very important, and $6 \%$ consider it important; $13 \%$ of men consider this subject to be very important, and 32\% consider it important.

The importance of the entrepreneurship course in designing and running a business is undeniable: $81 \%$ of women consider it useful and extremely useful whereas $89 \%$ of men find it useful and very useful.

The analysis of the results reveals some of the determinants of the entrepreneurial intentions in the case of the sample of Romanian entrepreneurs located in Southern Romania. In this respect, their residence, their previous overall business experience, their previous experience in specific 
business areas, their attitude towards entrepreneurship, their risk propensity, and their view on the role of useful courses in running a business, proved to be some of the most relevant. There are sensitive differences between the perception of men and women starting from their residence (urban/rural), their professional training and business experience. The respondents' attitude towards entrepreneurship demonstrates the level of their self-confidence and how important is the need for achievement.

PICBE | 121

The vast majority of the respondents are convinced that entrepreneurs bring certain benefits to society within they operate. This shows their confidence in the value of entrepreneurship in today's society. In most cases, there is a significant need to acquire new skills and knowledge from various disciplines, especially management and entrepreneurship. This demonstrates that the respondents are aware of the importance to learn more and improve their skills in order to successfully run their businesses.

The results validate the research hypothesis. They are in line with the result obtained by other researchers such as Cooney (2012), Loué and Baronet (2012), Morales and Marquina (2013), and Puta (2014).

\section{Conclusion}

The paper demonstrates that entrepreneurial intentions are key elements in starting the entrepreneurial process. This is why identifying and analyzing the determinants of entrepreneurial intentions constitutes both an interesting challenge and a valuable research effort.

The paper contributes to the enrichment of the scientific literature by emphasizing the role played by some of the main determinants of entrepreneurial intentions in the developing of entrepreneurship in Southern Romania. It shows that these determinants, in the case of the Romanian entrepreneurs located in Southern Romania, are related to both psychological and behavioral factors.

There are some limitations of the present research. First, the dimension of the sample is rather small. Second, other determinants of the entrepreneurial intentions should be identified and took into consideration. This is why future researches may focus on these issues.

\section{References}

Ajzen, I., \& Fishbein, M. (1980). Understanding attitudes and predicting social behavior. Englewood Cliffs, NJ: Prentice Hall.

Ajzen, I. (1991). The theory of planned behavior. Organizational Behavior and Human Decision Processes, 50(2), 179-211.

Bird, B. J. (1983). Intentional Maps of Entrepreneurs. Dissertation. Los Angeles, CA: University of Southern California.

Bird, B. J. (1988). Implementing entrepreneurial ideas: The case for intention. Academy of Management Review, 13(3), 442-453.

Bird, B. J. (2015). Entrepreneurial intentions research: A review and outlook. International Review of Entrepreneurship, 13(3), 143-168.

Blanchflower, D. G., \& Oswald, A. J. (1998). What makes an entrepreneur? Journal of Labor Economics, 16(1), 26-60.

Bosma, N., \& Kelley, D. (2018). Global Entrepreneurship Monitor 2018/2019 Global Report. Retrieved from https://www.gemconsortium.org/report/gem-2018-2019-global-report. 
Cooney, T. M. (2012). Entrepreneurship skills for growth-orientated businesses. Retrieved from https://www.iicie.com/uploads/White-

Paper/1463601177Cooney_entrepreneurship_skills_HGF.pdf

European Commission (2003). Green Paper: Entrepreneurship in Europe. Retrieved from http://europa.eu.int/comm/enterprise/entrepreneurship/green_paper/green_paper_final_en. pdf.

European Commission (2019). Annual Report on European SMEs 2018/2019: Research \& Development and Innovation by SMEs. Luxembourg: European Commission.

Ferreira, J. J., Raposo, M. L., Rodrigues, R. G., Dinis, A., \& do Paço, A. (2012). A model of entrepreneurial intention. Journal of Small Business and Enterprise Development, 19(3), 424-440.

Fini, R., Grimaldi, R., Marzocchi, G. L., \& Sobrero, M. (2012). The determinants of corporate entrepreneurial intention within small and newly established firms. Entrepreneurship Theory and Practice, 36(2), 387-414.

Fishbein, M., \& Ajzen, I. (1975). Belief, attitude, intention, and behavior: An introduction to theory and research. Reading, MA: Addison Wesley.

Gartner, W. B. (1988). "Who is an entrepreneur?" is the wrong question. American Journal of Small Business, 12(4), 11-32.

Gartner, W. B., Bird, B. J., \& Starr, J. A. (1992). Acting as if: Differentiating entrepreneurial from organizational behavior. Entrepreneurship Theory and Practice, 16(3), 13-32.

Herron, L., \& Robinson Jr., R. B. (1993). A structural model of the effects of entrepreneurial characteristics on venture performance. Journal of Business Venturing, 8(3), 281-294.

Iakovleva, T., \& Kolvereid, L. (2009). An integrated model of entrepreneurial intentions. International Journal of Business and Globalisation, 3(1), 66-80.

Low, M. B., \& MacMillian, I. C. (1988). Entrepreneurship: Past research and future challenges. Journal of Management, 14(2), 139-161.

Loué, C., \& Baronet, J. (2012). Toward a new entrepreneurial skills and competencies framework: a qualitative and quantitative study. International Journal of Entrepreneurship and Small Business, 17(4), 455-477.

McKenzie, B., Ugbah, S. D., \& Smothers, N. (2007). "Who is an entrepreneur?" is it still the wrong question? Academy of Entrepreneurship Journal, 13(1), 23-43.

Morales, C., \& Marquina, P. S. (2013). Entrepreneurial skills, significant differences between Serbian and German entrepreneurs. The Business and Economics Research Journal, 6(1), 129-141.

Moreira, A. C., Dantas, J. G. L., \& Valente, F. M. (Eds.) (2018). Nascent Entrepreneurship and Successful New Venture Creation. Hershey, PA: IGI Global.

Putta, S. S., (2014). Improving entrepreneur's management skills through entrepreneurship training. Journal of Commerce and Management Thought, 5(3), 459-474.

Rai, R. S., Prasad, A., \& Murthy, B. K. (2017). A review on intention models for predicting entrepreneurial behavior. Journal of Entrepreneurship Education, 20(2), 1-9.

Toma, S.-G., Grigore, A.-M., \& Marinescu, P. (2014). Economic development and entrepreneurhip. Procedia Economics and Finance, 8, 436-443.

Organisation for Economic Co-operation and Development (2019). OECD SME and Entrepreneurship Outlook 2019. Retrieved from http://www.oecd.org/industry/smes/ SME-Outlook-Highlights-FINAL.pdf.

Shapero, A., \& Sokol, L. (1982). Social dimensions of entrepreneurship. In Kent, C. A., Sexton, 
D. L., \& Vesper, K. H. (Eds.). Encyclopedia of Entrepreneurship (pp. 72-90). Englewood Cliffs, NJ: Prentice Hall.

Yildirim, N., Çakir, Ö., \& Așkun, O. B. (2016). Ready to dare? A case study on the entrepreneurial intentions of business and engineering students in Turkey. Procedia Social and Behavioral Sciences, 229, 277-288.

Walter, S.G., \& Heinrichs, S. (2015). Who becomes an entrepreneur? A 30-years-review of individual-level research. Journal of Small Business and Enterprise Development, 22(2), 225-248.

World Bank (2019). The changing nature of work. Retrieved from http://documents.worldbank. org/curated/en/816281518818814423/pdf/2019-WDR-Report.pdf. 